\title{
The urinary aromatic acids excreted by sheep given S24 perennial ryegrass cut at six stages of maturity
}

\author{
By A. K. MARTIN \\ Hannah Dairy Research Institute, Ayr \\ (Received ${ }_{5}$ December 1969-Accepted 27 April 1970)
}

I. S24 perennial ryegrass was harvested at six stages of its growth from young leafy herbage to mature grass in which the seed had shed.

2. Two sheep were offered $\mathrm{rkg} / \mathrm{d}$ of each cut and two other sheep were offered $75 \circ \mathrm{g} / \mathrm{d}$ of each cut of grass.

3. The contents of some possible precursors of the urinary aromatic acids excreted by sheep, namely, shikimic acid, quinic acid, chlorogenic acid, total $o$-dihydroxyphenolic compounds, lignin and crude protein were determined in each cut of grass.

4. A gas-liquid chromatographic method for the determination of the aromatic acids present in light petroleum extracts of urine was developed.

5. The urinary excretion of creatinine, diethyl ether-soluble acids, hippuric acid, total benzoic, phenylacetic and 3-phenylpropionic acids, and the apparent digestibilities of nitrogen, lignin and dry matter were determined with each sheep offered each cut of grass.

6. The quantity of the various aromatic acid fractions excreted by sheep decreased as the maturity of the herbage increased and was directly proportional to the amount of food consumed.

7. No relationship was found between the intake of possible benzoic acid precursors and the urinary excretion of benzoic acid. With diets of young herbage, smaller amounts of benzoic acid were excreted in the urine than would be predicted from the intakes of the precursors studied, and with mature herbage greater amounts were excreted than would be predicted.

8. Possible reasons for these results are discussed, and the nature of additional precursors of urinary aromatic acids excreted by sheep given mature herbages are considered.

9. Urinary excretion of phenylacetic acid varied with diet in a manner which closely followed the intake of apparently digestible nitrogen. A highly significant $(P<0.00 \mathrm{I})$ exponential relationship was found between these two variables; it was $\log _{10} E=0.05 \mathrm{~N}-0.63$, where $\mathrm{E}$ is the urinary phenylacetic acid output $(\mathrm{g} / \mathrm{kg}$ food) and $\mathrm{N}$ the intake of apparently digestible nitrogen $(\mathrm{g} / \mathrm{kg}$ food).

Earlier work in this laboratory has shown that urinary aromatic acid excretion by sheep is not directly related to their intake of crude protein, crude fibre, lignin or cellulose (Martin, I969a) although most of these aromatic acids are derived from dietary precursors (Martin, $1969 b$ ). Likely precursors of urinary aromatic acids are the phenolic acids (Harbourne \& Simmonds, I964), and quinic and shikimic acids which accumulate in grasses at certain stages of growth.

Oral administration of quinic or shikimic acids has frequently been shown to result in an enhanced urinary excretion of benzoic acid (Quick, I931; Beer, Dickens \& Pearson, I95 I ; Asatoor, I965). The caffeic acid (3:4-dihydroxycinnamic acid) moiety of chlorogenic acid (3-o-caffeoyl-D-quinic acid) is metabolized to a wide variety of products by man and rats (Booth, Emerson, Jones \& DeEds, 1957) and it is thought that the microflora of the intestinal tract plays an important part in these reactions. After oral treatment with the antibiotic neomycin, man does not aromatize quinic or shikimic acids (Asatoor, 1965 ). Booth \& Williams ( $1963 a$ ) have shown that cultures of micro-organisms from the intestinal tracts of a number of species metabolize caffeic 
acid; the aliphatic side-chain may be saturated and the 4 -hydroxyl group removed. The animal tissues may then shorten the aliphatic side-chain by $\beta$-oxidation and the 3 -hydroxyl group may be methylated. In view of the extensive microbial fermentations occurring in the rumen of sheep, it thus seemed possible that dietary quinic, shikimic and caffeic acids may be largely metabolized to aromatic acids.

A number of workers (Brigl \& Pfähler, I929; Ely, Kane, Jacobson \& Moore, I953; Pazur \& DeLong, r948) have reported that the consumption by herbivores of young leafy forages results in a greater urinary output of aromatic acids than does consumption of more mature forages. In the present paper the total $o$-dihydroxyphenolic compounds and chlorogenic, quinic and shikimic acid contents of the $\mathrm{S}_{24}$ strain of perennial ryegrass cut at six different stages of growth are reported. These herbages have been given to sheep and the manner in which urinary aromatic acid excretion varied with intakes of the postulated precursors has been examined.

\section{EXPERIMENTAL}

\section{Description and storage of herbage}

The dates on which the pure stand of $\mathrm{S}_{24}$ perennial ryegrass was harvested and a description of the stage of growth of the different cuts are recorded in Table 1 .

Grass from cuts $1-5$ inclusive was frozen and stored at $-10^{\circ}$ in a commercial cold store until required for feeding. The cut grass was removed from the sward as quickly

Table I. Dates of cutting, lengths of cut stems and proportion of leaf tissue (\% of dry matter) of $S_{2} 4$ perennial ryegrass cut at six stages of growth

$\begin{array}{clccc}\text { Cut no. } & \text { Description } & \text { Date } & \begin{array}{c}\text { Mean length } \\ \text { of cut stems } \\ (\mathrm{cm})\end{array} & \begin{array}{c}\text { Proportion } \\ \text { of leaf } \\ (\% \text { dry matter) }\end{array} \\ 1 & \text { Leafy, some stem } & \text { 4 May } & 6 & 80 \cdot 3 \\ 2 & \text { Seed heads about to emerge } & \text { I8 May } & \text { II } & 67 \cdot 9 \\ 3 & \text { Seed heads fully emerged } & \text { 8 June } & 3 \mathrm{I} & 27 \cdot 2 \\ 4 & \text { Seed set } & \text { 29 June } & 53 & 21 \cdot 3 \\ 5 & \text { Seed ripe } & \text { 3 August } & 74 & 0 \cdot 0 \\ 6 & \text { Leafy grass, no stem } & \text { 5 September } & \circ & 100 \cdot 0\end{array}$

as possible and thoroughly mixed. A rapid estimate of its dry-matter content was made by drying small samples in a forced-draught oven at $105^{\circ}$ for $30 \mathrm{~min}$. The fresh weight equivalent to 500 and $375 \mathrm{~g}$ dry matter was weighed into $5^{\mathrm{I}} \times 76 \mathrm{~cm}$ polyethylene bags ( 500 gauge, $0^{\circ} 13 \mathrm{~mm}$ thick). A small piece of solid carbon dioxide was added to each bag which was then evacuated and sealed with a rubber ring. As soon as the required number of bags had been filled (about $6 \mathrm{~h}$ after the grass was cut) the samples were placed in the cold store. The period of storage varied from 2 to 8 weeks for each cut.

The grass of cut 6 was dried in a forced-draught barn grass drier to $95 \%$ dry matter. Rations of 500 or $375 \mathrm{~g}$ dry matter were weighed into polyethylene bags and stored at $5^{-10^{\circ}}$ until required. The period of storage of this barn-dried grass varied from 7 to 12 weeks. 


\section{Animals}

The four wether sheep (nos. I-4) were those described by Martin (1969 $b$ ).

\section{Plan of experiment}

The experiment consisted of six 3 -week experimental periods, during which each sheep was given the six cuts of grass in the order in which they were cut; i.e. during period I, cut I herbage was given to the sheep and, during period 2 , cut 2 herbage was given, and so on. Periods $\mathrm{I}-5$ inclusive, followed each other without a break, but there was an interval of 9 weeks between periods 5 and 6 .

Table 2. Mean dry-matter intakes by each sheep $(\mathrm{g} / 24 \mathrm{~h})$ of each cut of $S 24$ perennial ryegrass

\begin{tabular}{crc} 
Cut no. & \multicolumn{1}{c}{ Sheep nos. } \\
I & 959 & 3,4 \\
2 & 1024 & 719 \\
3 & 1008 & 768 \\
4 & 994 & 756 \\
5 & $*$ & 750 \\
6 & 1026 & 677 \\
& & 770
\end{tabular}

* Sheep refused some of the 'high level' rations of cut 5 . The mean daily intake of these sheep during the last $7 \mathrm{~d}$ of each feeding period was: sheep I, $920 \mathrm{~g} / 24 \mathrm{~h}$; sheep $2,907 \mathrm{~g} / 24 \mathrm{~h}$.

Sheep were given food at 06.00 hours and 16.00 hours each day. Sheep nos. I and 2 were given amounts of herbage calculated to contain $500 \mathrm{~g}$ dry matter ('high level') and sheep nos. 3 and 4 were given amounts of herbage calculated to contain $375 \mathrm{~g}$ dry matter ('low level') per feed. The exact daily intake of grass by each sheep is given in Table 2 . During period 5 , sheep nos. I and 2 refused considerable quantities of food. The food left was removed at the end of each $24 \mathrm{~h}$ period and its dry matter determined to enable the dry-matter consumption to be calculated.

During the final $7 \mathrm{~d}$ of each feeding period, the total amounts of faeces and urine excreted were collected and weighed; samples were then taken for the analyses described below. The sheep harness, urine-collection apparatus and the method of preserving the urine have been described previously (Martin, I966). The samples were stored at $4^{\circ}$, and at the end of the $7 \mathrm{~d}$ collection period a fixed proportion of the total amount of faeces and urine excreted was bulked to give composite samples. A known weight of water was added to the sample of bulked faeces and the mixture was homogenized (Model AX homogenizer; Silverson Machines Ltd, London) to give a slurry. 


\section{Methods of analysis}

Grasses

Shikimic acid, quinic acid, total ortho-dihydroxyphenolic compounds and chlorogenic acid. Details of the analytical techniques used will be described elsewhere (A. K. Martin, to be published). Shikimic and quinic acids were determined by ion-exchange chromatography of aqueous extracts of milled herbage. Total $o$-dihydroxyphenolic compounds were estimated by the colorimetric technique described by Zucker \& Ahrens (1958). This estimate includes chlorogenic acid and other aromatic compounds having two vicinal hydroxy groups in the aromatic ring. However, the colours given by different dihydroxyphenolic compounds vary, so these results give only an approximation to the total $o$-dihydroxyphenolic compounds present. Chlorogenic acid was determined by the u.v. absorption of eluates of appropriate regions of paper chromatograms of methanol extracts of grass.

Lignin. The method of Czerkawski ( 1967 ) was used.

Nitrogen. The macro-Kjeldahl digestion technique using copper sulphate and selenium catalysts was used. Ammonia was distilled into boric acid and titrated with standard acid.

\section{Urine}

Creatinine. The urinary creatinine output in all experiments was determined daily for the last $7 \mathrm{~d}$ of each feeding period. Urine was diluted as described previously (Martin, $1969 b$ ) and its content of creatinine determined by the method of McEvoyBowe (1966). Hippuric acid when present in large concentrations in the urine interfered with this method, so urine samples from the sheep given cut 6 herbage were analysed by the modified Jaffe reaction described by Taussky (1956). In this method, compounds interfering with the Jaffe reaction are removed by a preliminary extraction of the urine with peroxide-free diethyl ether.

Solvent extraction of urine and the determination of the titratable acidity of solvent extracts

Unhydrolysed urine. Diethyl ether and light petroleum (boiling range $40-60^{\circ}$ ) extracts were made on the last $3 \mathrm{~d}$ of each $7 \mathrm{~d}$ collection period. Urine was acidified to a $\mathrm{pH}$ of between $\mathrm{I}$ and 2 with $6 \mathrm{~N}-\mathrm{HCl}$ and saturated with $\mathrm{NaCl}$ prior to solvent extraction for a $20 \mathrm{~h}$ period. The acidities of these extracts were determined as described by Martin (1969a).

Hydrolysed urine. Urine was hydrolysed by heating for $\mathrm{I} 6 \mathrm{~h}$ with $10 \mathrm{~N}-\mathrm{KOH}$ $\left(0.125\right.$ vol.) in a sealed tube maintained at $95^{\circ}$. The hydrolysed urine was then extracted with diethyl ether or light petroleum (boiling range $40-60^{\circ}$ ) as described for unhydrolysed urine. No daily urine samples were hydrolysed during period I or for sheep $\mathrm{I}$ and 3 during period 2.

Portions of the bulked urine sample from all sheep in all periods were hydrolysed and extracted with light petroleum (boiling range $40-60^{\circ}$ ). The extract was made to a known volume with light petroleum and a portion used for the determination of 
titratable acidity; two further portions were used for the determination of the nature of the acids present in the extracts.

The acidities of all extracts are reported in terms of benzoic acid equivalent (BAE) extracted in $24 \mathrm{~h}$.

Hippuric acid. This was determined in diethyl ether extracts of unhydrolysed urine as previously described (Martin, $1969 b$ ).

Benzoic acid. The method described by Martin $(1969 b)$ was used for the quantitative determination of benzoic acid in light petroleum extracts of hydrolysed urine.

Table 3. Retention times and response factors relative to those of benzoic acid on gasliquid chromatography of free aromatic acids on columns of $5 \%$ w/w Carbowax $20 M / T P A$ and the products of the relative response factors of each acid and its molecular weight

(The results are the means of two experiments. The range is shown in parentheses. Only one experiment was made with cinnamic and 2-phenylbutyric acids)

\begin{tabular}{|c|c|c|c|}
\hline Acid & $\begin{array}{l}\text { Relative } \\
\text { retention } \\
\text { time }\end{array}$ & $\begin{array}{l}\text { Relative } \\
\text { response } \\
\text { factor }\end{array}$ & $\begin{array}{c}\text { Relative response } \\
\text { factor } \times \text { molecular } \\
\text { weight }\end{array}$ \\
\hline Benzoic & $x \cdot 00$ & $x \cdot \infty$ & 122 \\
\hline Phenylacetic & $\begin{array}{c}\mathrm{I} \cdot 5 \mathrm{I} \\
\left(\mathrm{I} \cdot 5^{\mathrm{I}-\mathrm{I}} \cdot 5^{2}\right)\end{array}$ & $\begin{array}{c}I \cdot 25 \\
(I \cdot 23-I \cdot 26)\end{array}$ & $\begin{array}{c}170 \\
(168-172)\end{array}$ \\
\hline 3-Phenylpropionic & $\begin{array}{c}I \cdot 9 I \\
(I \cdot 90-I \cdot 9 I)\end{array}$ & $\begin{array}{c}I \cdot 20 \\
(I \cdot 19-I \cdot 20)\end{array}$ & $\begin{array}{c}180 \\
(177-183)\end{array}$ \\
\hline 4-Phenylbutyric & $\begin{array}{c}2.57 \\
\left(2 \cdot 5^{1-2 \cdot 58)}\right.\end{array}$ & $\begin{array}{c}I .08 \\
(I .06-I \cdot I I)\end{array}$ & $\begin{array}{c}178 \\
(174-182)\end{array}$ \\
\hline 5-Phenylvaleric & $\begin{array}{c}3.92 \\
(3.85-3.92)\end{array}$ & $\begin{array}{c}0.91 \\
(0.89-0.94)\end{array}$ & $\begin{array}{c}163 \\
(159-168)\end{array}$ \\
\hline 2-Phenylbutyric & $x \cdot 76$ & - & - \\
\hline Cinnamic & 3.92 & $\mathrm{I} \cdot 59$ & 232 \\
\hline
\end{tabular}

Gas-liquid chromatography of aromatic acids. Scott, Ward \& Dawson (I964) have described a gas-liquid chromatographic separation of the methyl esters of some aromatic and phenolic acids. Difficulty was experienced in avoiding losses of the very volatile methyl benzoate during methylation of mixtures of pure benzoic, phenylacetic and 3-phenylpropionic acids. In view of these losses the free acids were separated in the present experiments, a suitable liquid phase being found to be Carbowax $20 \mathrm{M} / \mathrm{TPA}$ (Perkin-Elmer Ltd, Beaconsfield, Bucks.) which had previously been used by Hill \& Hill (I964) for the separation of variously substituted benzoic acids. A Pye Argon chromatograph equipped with a $\beta$-ionization detector was used. Between Io and $30 \mu \mathrm{g}$ of pure acids in anhydrous diethyl ether were injected on to glass columns (120 cm long, $5 \mathrm{~mm}$ bore) filled with dimethylchlorosilane-treated Chromosorb $\mathrm{G}$ containing $5 \%(\mathrm{w} / \mathrm{w})$ of the liquid phase. The column was maintained at $180^{\circ}$; the argon carrier gas pressure was 0.9 bar and the flow rate was $50 \mathrm{ml} / \mathrm{min}$.

The retention times of the aromatic acids relative to benzoic acid and the response factors (peak area divided by weight injected) for each acid relative to benzoic acid are described in Table 3 . The relative responses of the different acids varied but the response per mole (relative responses $\times$ molecular weight, Table 3 ) was almost constant 
for all except benzoic and cinnamic acids. Benzoic acid was atypical in giving a response that was only $70 \%$ of the average response given by other acids of the homologous series; cinnamic acid gave a much greater response than the acids with a saturated aliphatic side-chain.

\section{Faeces}

Lignin. The dry matter of a portion of the faecal slurry prepared from the $7 \mathrm{~d}$ composite faeces sample was determined by drying in an oven at $105^{\circ}$ to constant weight. The dried faeces sample was milled in a Christy and Norris hammer mill and its lignin content determined by the method of Czerkawski (1967).

Nitrogen. The nitrogen content of the faecal slurry was determined by the method described for grass analyses.

\section{RESULTS}

\section{Analyses of grass samples}

The contents of total $o$-dihydroxyphenolic compounds, chlorogenic acid, shikimic acid, quinic acid, lignin and crude protein $(\mathrm{N} \times 6.25)$ are presented in Table 4 . The possible significance of the relationships of these components to each other and to the

Table 4. Contents (\% of dry matter) of total o-dihydroxyphenolic compounds (calculated as chlorogenic acid), chlorogenic acid, shikimic acid, quinic acid, lignin and crude protein $(N \times 6 \cdot 25)$ in perennial ryegrass (variety $\left.S_{24}\right)$ cut at six stages of maturity

\begin{tabular}{|c|c|c|c|c|c|c|}
\hline Cut & $\begin{array}{c}\text { Total } \\
\text { o-dihydroxy } \\
\text { phenolic } \\
\text { compounds } \\
(\%)\end{array}$ & $\begin{array}{c}\text { Chlorogenic } \\
\text { acid } \\
(\%)\end{array}$ & $\begin{array}{l}\text { Shikimic } \\
\text { acid } \\
(\%)\end{array}$ & $\begin{array}{l}\text { Quinic } \\
\text { acid } \\
(\%)\end{array}$ & $\underset{(\%)}{\text { Lignin }}$ & $\begin{array}{c}\text { Crude } \\
\text { protein } \\
(\%)\end{array}$ \\
\hline I & $I \cdot 54$ & I'04 & 0.06 & 0.53 & 2.70 & 19.7 \\
\hline 2 & 0.85 & 0.54 & 0.08 & 0.49 & 3.41 & I3.0 \\
\hline 3 & 0.76 & 0.39 & 0.07 & 0.25 & 5.02 & 8.0 \\
\hline 4 & 0.35 & 0.12 & 0.01 & 0.12 & $6 \cdot 83$ & 5.4 \\
\hline 5 & 0.29 & 0.06 & 0.00 & 0.05 & 7.58 & 47 \\
\hline 6 & $I \cdot 22$ & 0.67 & 0.30 & $0.6 \mathrm{I}$ & $2 \cdot 76$ & I 5.7 \\
\hline
\end{tabular}

anatomical composition of the plant will be discussed elsewhere (A. K. Martin, to be published). All compounds or fractions other than lignin decreased in concentration with increasing maturity. Shikimic acid was present in appreciable concentrations only in the young, leafy autumn herbage (cut 6). Only small amounts of chlorogenic acid and quinic acid were found in the more mature herbages (cuts 4 and 5). Qualitative estimates of flavonoids (A. K. Martin, to be published) indicated that they increased in number and concentration with increasing maturity of the grass.

\section{Weights of animals}

All sheep were weighed at the beginning and end of the $7 \mathrm{~d}$ period during which faeces and urine were collected. The averages of these two weights $(\mathrm{kg})$ of the sheep during periods I, $2,3,4,5$ and 6 respectively were: sheep no. I, $60 \cdot 4,64 \cdot 5,68 \cdot 5,69 \cdot 1$, 
$67 \cdot 6$ and $60 \cdot 6$; sheep no. $2,70 \cdot 0,71 \cdot 6,76 \cdot 4,76 \cdot 5,74 \cdot 4$ and $69 \cdot 9$; sheep no. $3,63 \cdot 3$, $65 \cdot 8,68 \cdot 9,68 \cdot 7,65 \cdot 6$ and $63 \cdot 1$; sheep no. $4,70 \cdot 4,72 \cdot 2,74 \cdot 0,73 \cdot 4,69 \cdot 5$ and $62 \cdot 7$. All sheep gained weight during periods $\mathrm{I}-3$ inclusive; during period 4 those sheep on the high level of feeding (nos. I and 2) maintained their weight while those on the low level of feeding (nos. 3 and 4 ) lost weight. All sheep lost weight during period 5 when the most mature herbage was given. Further losses in weight occurred between periods 5 and 6 when the animals were used in other experiments, but during period 6 when the least mature herbage was given to sheep all the animals increased in weight.

\section{Creatinine excretion}

Analysis of variance showed that there were significant differences between sheep (0.00I $<P<0.01)$ and between periods $(P<0.001)$ in urinary creatinine output. The mean creatinine $(\mathrm{g} / 24 \mathrm{~h})$ values for the sheep given the high level (nos. I and 2 ) and low level (nos. 3 and 4 ) of each cut of herbage were respectively: cut I, I.26 and $\mathrm{I} \cdot 24$; cut $2, \mathrm{I} \cdot 26$ and $\mathrm{I} \cdot 20$; cut $3, \mathrm{I} \cdot 09$ and 0.95 ; cut $4,0.88$ and $\mathrm{I} \cdot 02$; cut $5,0.85$ and 0.85 and cut $6,0.86$ and 0.82 .

Level of feeding was not the most important factor in the significant differences observed between sheep. In four of the six periods (nos. I, 2, 5 and 6) very similar mean creatinine values were found at both levels of feeding. Variation within a feeding level was, in some periods, considerably greater than that found between feeding levels. Thus, in period I the urinary creatinine excretion $(\mathrm{g} / 24 \mathrm{~h}$ ) of sheep nos. I and 2 (high level) was $\mathrm{I} \cdot 34$ and $\mathrm{I} \cdot \mathrm{I} 8 \mathrm{~g}$ respectively and that of sheep nos. 3 and 4 (low level) was $\mathrm{I} \cdot \mathrm{II}$ and $\mathrm{I} \cdot 37 \mathrm{~g}$ respectively.

During the experiment there was (with the exception of sheep given the low level of cut 4 herbage) a continuing decrease in urinary creatinine output. The maximum mean output was $\mathrm{I} \cdot 26 \mathrm{~g} / 24 \mathrm{~h}$ when the high level of cut $\mathrm{I}$ herbage was given to sheep at the start of the experiment and the minimum mean output was $0.82 \mathrm{~g} / 24 \mathrm{~h}$ when sheep were given the low level of cut 6 herbage at the end of the experiment. Van Niekerk, Reid, Bensadoun \& Paladines (1963) have shown that urinary excretion of creatinine is correlated with the total protein present in the body tissues of sheep. The mean nitrogen balance $(\mathrm{g} / 24 \mathrm{~h})$ values for sheep given the high or low level of each cut of herbage were, respectively: cut $I,+I \cdot 9$ and $+I \cdot 0$; cut $2,+3.3$ and $+0 \cdot I$; cut $3,+\mathrm{I} \cdot 8$ and +0.8 ; cut $4,-0.4$ and $-\mathrm{I} \cdot 3$; cut $5,-3.0$ and -2.6 and cut $6,+6.6$ and $+3 \cdot 5$. Changes in total body protein mass could account, in part at least, for the observed variations in urinary creatinine excretion. Thus, during periods 4 and 5 when all sheep were in negative nitrogen balance the urinary creatinine output (mean for all sheep; $0.95 \mathrm{~g}$ in period 4 and 0.85 in period 5 ) was less than in periods $\mathrm{I}$ and 2 when all sheep were in positive $\mathrm{N}$ balance and gaining weight (mean for all sheep; $\mathrm{I} \cdot 25 \mathrm{~g}$ in period $\mathrm{I}$ and $\mathrm{I} \cdot 20 \mathrm{~g}$ in period 2). The low urinary creatinine output of $0.84 \mathrm{~g} / 24 \mathrm{~h}$ (mean for all sheep) found in period 6 probably was due to protein depletion occurring during periods 4 and 5 and also during the intervening time between periods 5 and 6 . The very large positive nitrogen balances observed during this period would support the contention that body protein reserves were much depleted prior to this period. Alteration in the total mass of body protein would not explain the reduced 
creatinine excretion observed during period 3 when all sheep were in positive nitrogen balance and gaining weight. No explanation is to hand for this result.

\section{Total benzoic acid equivalent in urine extracts}

Diethyl ether will completely extract the following classes of acids from acidified aqueous solutions ( $\left.\mathrm{pH}_{\mathrm{I}}-2\right)$; aliphatic acids (e.g. oxalic, citric), aromatic acids (e.g. benzoic acid and its homologues, cinnamic acid), phenolic acids (e.g. $p$-hydroxyphenylacetic), and indolyl acids (e.g. indole acetic) and conjugates of these acids with glycine or glucuronic acid (although not all glucuronides are diethyl ether-soluble). Light petroleum (boiling range $40-60^{\circ}$ ) will only extract unconjugated aromatic acids under these conditions (Martin, $1969 a$ ).
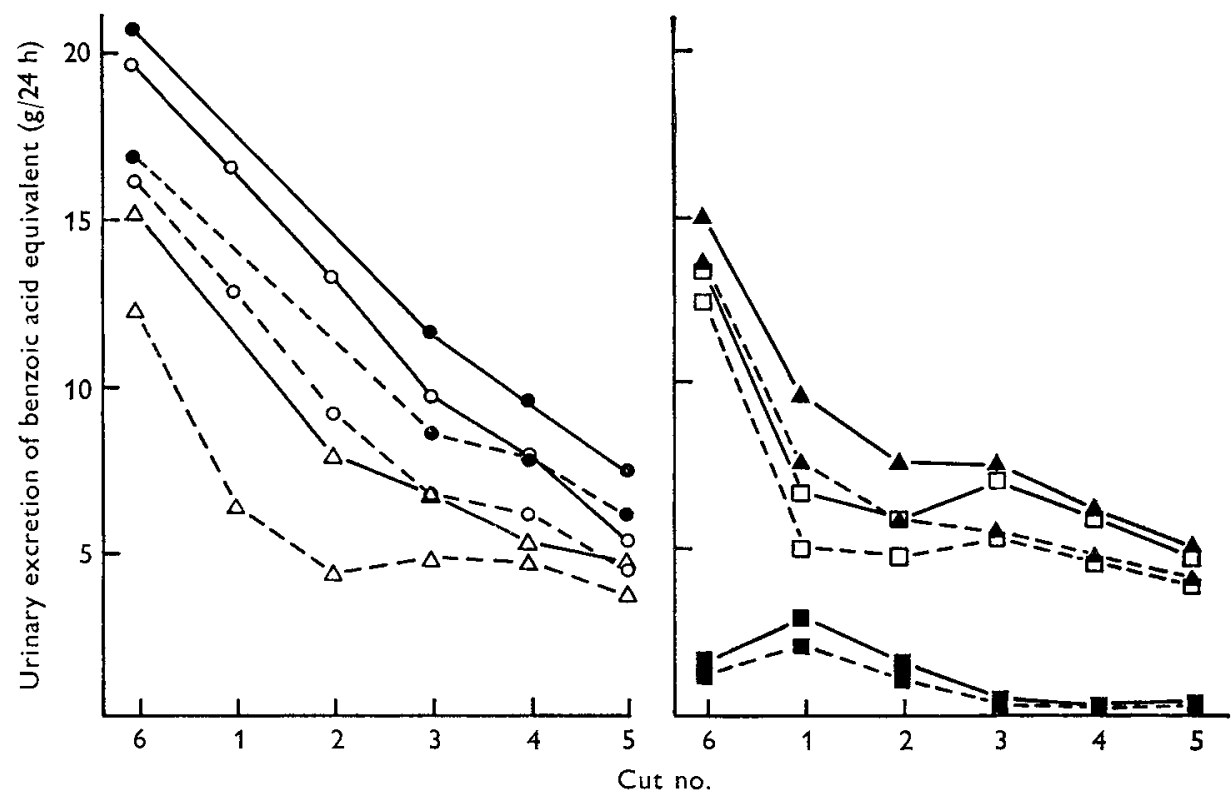

Fig. r. Mean total urinary excretion of benzoic acid equivalent $(\mathrm{g} / 24 \mathrm{~h})$, in each of the urine fractions examined, in two sheep with high and two sheep with low intakes of each of six cuts of S24 ryegrass. - - , high levels of feeding; ---, low levels of feeding. 9 , diethyl ethersoluble acids of hydrolysed urine; $O$, diethyl ether-soluble acids of unhydrolysed urine; $\triangle$, hippuric acid plus the free aromatic acids found in light petroleum extracts of unhydrolysed urine; $\boldsymbol{\Delta}$, total aromatic acids in light petroleum extracts of hydrolysed urine; $\square$, total benzoic acid (i.e. free plus conjugated); $\boldsymbol{m}$, total phenylacetic acid (i.e. free plus conjugated).

The average output of $\mathrm{BAE} / 24 \mathrm{~h}$ in each of the various urine fractions examined was calculated as follows. Analyses were made on three consecutive $24 \mathrm{~h}$ urine samples during the $7 \mathrm{~d}$ experimental period and the results of these analyses were expressed in terms of $\mathrm{g} \mathrm{BAE} / \mathrm{g}$ creatinine excreted each day. 'The mean of the seven daily creatinine analyses was then used to calculate the average daily BAE output for the period. The accuracy of this procedure for estimating the urinary aromatic acid output during the experimental periods was checked by determining the titratable acids present in light petroleum extracts of a hydrolysed portion of the composite urine sample for each 
period. No significant differences were found between these values and those calculated from individual daily analyses.

The average urinary excretions of BAE by the two sheep (nos. I and 2) on the high level of intake ( $\mathrm{I} \mathrm{kg} \mathrm{herbage/24} \mathrm{h)} \mathrm{and} \mathrm{by} \mathrm{the} \mathrm{two} \mathrm{(nos.} 3$ and 4 ) on the low level of intake ( $75^{\circ} \mathrm{g}$ herbage $/ 24 \mathrm{~h}$ ) are shown in Fig. I.

These results suggest that the urinary output of BAE in all fractions was derived largely from the food and was directly proportional to the amount consumed, since the BAE excretion of sheep given each cut of herbage at the low level of intake was almost exactly $75 \%$ of that of sheep given the same cut at the high level of intake. The excre-

Table 5. Mean urinary output of benzoic acid equivalent $/ 24 h$ by four sheep expressed as $\mathrm{g} / \mathrm{kg}$ food intake when they were given $S \mathbf{2 4}$ ryegrass cut at six different stages of maturity

\begin{tabular}{|c|c|c|c|}
\hline \multirow[b]{2}{*}{ Cut } & \multicolumn{2}{|c|}{$\begin{array}{l}\text { Diethyl ether-soluble } \\
\text { acids }\end{array}$} & \multirow[b]{2}{*}{$\begin{array}{l}\text { Hippuric } \\
\text { acid }\end{array}$} \\
\hline & $\begin{array}{l}\text { Urine } \\
\text { hydrolysed }\end{array}$ & $\begin{array}{l}\text { Urine un- } \\
\text { hydrolysed }\end{array}$ & \\
\hline I & ND & I $7 \cdot 53$ & 6.73 \\
\hline 2 & 12.80 & I 2.45 & 4.70 \\
\hline 3 & II 35 & $9 \times 9$ & $3 \cdot 18$ \\
\hline 4 & $9 \cdot 94$ & 7.95 & 4.00 \\
\hline 5 & 8.47 & $6 \cdot 12$ & 3.92 \\
\hline 6 & $21 \cdot 88$ & $20 \cdot 76$ & 13.57 \\
\hline $\begin{array}{l}\text { Standard } \\
\text { error }\end{array}$ & 0.54 & 0.56 & 0.47 \\
\hline $\begin{array}{l}\text { Difference } \\
\text { in means } \\
\text { required for } \\
P<0.05\end{array}$ & $2 \cdot 59$ & $2 \cdot 57$ & $2 \cdot 20$ \\
\hline
\end{tabular}

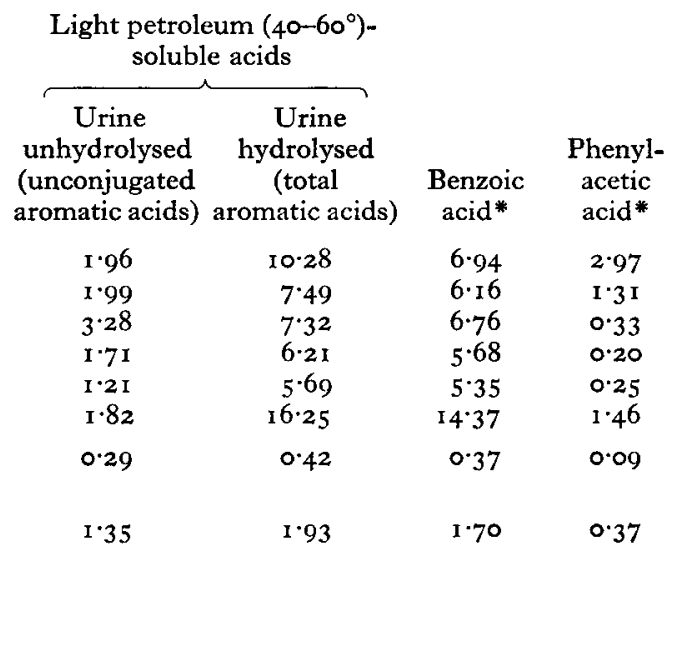

* Aromatic acids in light petroleum extracts of hydrolysed urine. Values for benzoic acid are means of the results with two analytical techniques (see p. 953).

ND, not determined.

tions of the various urinary fractions by the sheep on the low level of intake when expressed as a percentage of those excreted on the high level of intake were: diethyl ether-soluble acids of hydrolysed urine, $79 \%$; diethyl ether-soluble acids of unhydrolysed urine $76 \%$; hippuric acid, $78 \%$; benzoic acid, $82 \%$ and phenylacetic acid $88 \%$. The hippuric acid fraction included the unconjugated aromatic acids which probably arose as a result of hydrolysis of aroyl-glycine conjugates in the urine during the $24 \mathrm{~h}$ collection periods. (The free benzoic acid content of the urine samples analysed was not separately determined.) The closeness of these values to $75 \%$ confirms the view that the urinary output of $\mathrm{BAE}$ is proportional to the herbage intake, and the results for BAE output in all fractions by all sheep during each period were therefore expressed in terms of $\mathrm{g} \mathrm{BAE} / \mathrm{kg}$ food intake. The results obtained were subjected to analyses of variance and, with the exception of the results for hippuric acid and light petroleum-soluble acids of unhydrolysed urine, no significant differences between 
sheep were detected. The differences between periods were highly significant $(P<0.001)$ in all instances.

The mean results for the excretion of each fraction by all sheep in terms of $\mathrm{g}$ BAE excreted per $\mathrm{kg}$ food intake $/ 24 \mathrm{~h}$ are given in Table 5 , together with their standard errors and differences between means required for significance at the $5 \%$ level of probability.

Diethyl ether-soluble acids. Consistently smaller amounts of diethyl ether-soluble acids were extracted from unhydrolysed urine than from hydrolysed urine (Table 5) due probably to the presence in the former of diethyl ether-insoluble acid conjugates (e.g. sulphate esters of phenolic acids or diethyl ether-insoluble glucuronides; Bray, Ryman \& Thorpe, 1947). The amounts of diethyl ether-soluble acids of both hydrolysed and unhydrolysed urine decreased markedly as the maturity of the herbage increased; the greatest amounts $(2.1 .9 \mathrm{~g} \mathrm{BAE} / \mathrm{kg}$ food in hydrolysed and $20.8 \mathrm{~g} \mathrm{BAE} / \mathrm{kg}$ food in unhydrolysed urine) were excreted by the sheep given the least mature herbage (cut 6) and the smallest amounts $(8.47 \mathrm{~g} \mathrm{BAE} / \mathrm{kg}$ food in hydrolysed and $6.12 \mathrm{~g} \mathrm{BAE} /$ $\mathrm{kg}$ food in unhydrolysed urine) by the sheep given the most mature herbage (cut 5).

Hippuric acid and light petroleum-soluble acids of hydrolysed urine. These two fractions were the only ones in which analysis of variance showed significant differences between sheep (0.00I $<P<0.01$ for hippuric acid; $0.01<P<0.05$ for titratable acids of light petroleum extracts of unhydrolysed urine). Analysis of variance of the sums of the BAE found on analysis as hippuric acid and as free aromatic acids (i.e. light petroleum-soluble acids of unhydrolysed urine) failed to detect any significant differences between sheep although the differences between periods were significant $(P<0.001)$. Hippuric acid readily decomposes to benzoic acid and glycine in sheep urine (Martin, I $1969 \mathrm{~b}$ ). It is possible therefore that the significant differences found between sheep in the hippuric acid content of their urine reflect differences in the rate of hippuric acid hydrolysis in the urine rather than differences in the quantity excreted.

Hippuric acid excretion decreased more rapidly with increasing maturity of the herbage than did the excretion of diethyl ether-soluble acids (Table 5). Again, the greatest quantities $(13.6 \mathrm{~g} \mathrm{BAE} / \mathrm{kg}$ food) were excreted by sheep offered the least mature herbage (cut 6$)$ and the smallest $(3.92 \mathrm{~g} \mathrm{BAE} / \mathrm{kg}$ food) by those sheep given the most mature herbage (cut 5).

Total aromatic acids. The urinary excretion of this fraction (i.e. the titratable acids of light petroleum extracts of hydrolysed urine) also decreased as the maturity of the herbage consumed increased (see Table 5). Once more, the largest output of urinary $\mathrm{BAE}$ ( $\mathrm{I} \cdot 3 \mathrm{~g} \mathrm{BAE} / \mathrm{kg}$ food) was observed with sheep given the least mature herbage (cut 6) and the smallest $(5.69 \mathrm{~g} \mathrm{BAE} / \mathrm{kg}$ food) by sheep given the most mature herbage (cut 5).

Partition of the total aromatic acids. The concentration of benzoic acid in light petroleum extracts of hydrolysed urine was determined by u.v. spectrophotometry. However, this method cannot be used for the estimation of phenylacetic and 3-phenylpropionic acids. The proportions of benzoic, phenylacetic and 3-phenylpropionic acids present were determined by gas-liquid chromatography. The product of the total aromatic acid output and the proportion of the aromatic acids found by gas-liquid chromatography as benzoic acid gave total benzoic acid outputs that were not significantly different from 
those obtained by u.v. spectrophotometry. Amounts of other aromatic acids in the light petroleum extracts were calculated using the mean of the two estimates of benzoic acid and the proportions found by gas-liquid chromatography. In nearly all instances phenylacetic acid was the only other acid present although during two periods one sheep (no. 2) excreted small quantities of 3-phenylpropionic acid; during periods 2 and 4 this acid accounted for 4.8 and $0.8 \%$ respectively of the total urinary aromatic acids. In further discussion 3-phenylpropionic acid, when present, is included in the benzoic acid fraction.

The trend in benzoic acid excretion with increasing maturity of the herbage was very similar to that observed for hippuric acid. Again, the largest quantities $\left(14^{\circ} \cdot \mathrm{g}\right.$ $\mathrm{BAE} / \mathrm{kg}$ food) were observed with sheep given the least mature herbage (cut 6) and the smallest $(5.35 \mathrm{~g} \mathrm{BAE} / \mathrm{kg}$ food) when the sheep were offered the most mature herbage (cut 5) (Table 5). Phenylacetic acid excretion was at a maximum when cut I herbage was offered (2.97 $\mathrm{g} \mathrm{BAE} / \mathrm{kg}$ food) with considerable quantities being excreted with cuts 6 and 2 . The smallest excretion of phenylacetic acid was observed when cut 4 was given ( $0.20 \mathrm{~g} \mathrm{BAE} / \mathrm{kg}$ food).

\section{Apparent digestibility of dietary dry matter, nitrogen and lignin}

Analyses of variance showed that there were no significant differences between sheep for the apparent digestibilities of dry matter and nitrogen or for the percentage recovery of dietary lignin in the faeces; for all three constituents there were significant

Table 6. Mean apparent digestibility of dry matter and nitrogen, intake of apparently digestible nitrogen and faecal recovery of dietary lignin when four sheep were given $S_{24}$ ryegrass cut at six different stages of maturity

\begin{tabular}{|c|c|c|c|c|}
\hline \multirow[b]{2}{*}{ Cut } & \multicolumn{2}{|c|}{ Apparent digestibility (\%) } & \multirow{2}{*}{$\begin{array}{c}\text { Intake of apparently } \\
\text { digestible nitrogen } \\
(\mathrm{g} / \mathrm{kg} \text { food })\end{array}$} & \multirow{2}{*}{$\begin{array}{l}\text { Lignin in faeces } \\
(\% \text { of lignin in diet })\end{array}$} \\
\hline & Dry matter & Nitrogen & & \\
\hline I & $83 \cdot 3$ & 79.3 & 25.0 & $76 \cdot 7$ \\
\hline 2 & $80 \cdot 4$ & $69 \cdot 9$ & 14.5 & $78 \cdot 1$ \\
\hline 3 & $75 \cdot 5$ & $54 \%$ & $7 \cdot 0$ & $87 \cdot 9$ \\
\hline 4 & $63 \cdot 5$ & $35 \cdot 2$ & $I \cdot 9$ & 103.9 \\
\hline 5 & $57^{\circ} 0$ & II'I & 0.8 & 102.4 \\
\hline 6 & $74 \cdot 1$ & $76 \cdot 1$ & $19^{\circ} \mathrm{I}$ & $96 \cdot 9$ \\
\hline $\begin{array}{l}\text { Standard } \\
\text { error }\end{array}$ & $2 \cdot 4$ & $2 \cdot 4$ & $\longrightarrow$ & $2 \cdot 3$ \\
\hline $\begin{array}{l}\text { Difference in } \\
\text { means required } \\
\text { for } P<0.05\end{array}$ & 10.9 & $I I \cdot O$ & - & 10.4 \\
\hline
\end{tabular}

differences between cuts $(P<0.00 \mathrm{I})$. The mean values for the apparent digestibilities of dry matter and nitrogen and for the recoveries of lignin in the faeces are given in Table 6, together with their standard errors and the differences between means required for significance at the $5 \%$ level of probability. The total intake of apparently digestible nitrogen is also given in this table.

Although the dry matter of cut $\mathrm{I}$ herbage showed the greatest apparent digestibility, 
the only significant difference between successive cuts was that observed between periods 3 and 4 (a decrease from 75.5 to $63.5 \%$ respectively).

The differences in apparent digestibilities of nitrogen were much greater than those found for the dry-matter digestibilities. Again, the nitrogen of cut I herbage showed the greatest apparent digestibility $(79.3 \%)$, and the apparent digestibility decreased with further increase in herbage maturity to the very low value of $I$ I $I \%$ found during period 5 .

The recovery of dietary lignin was not significantly different from $100 \%$ in periods 6,4 and 5 . In periods 1,2 and 3 lignin was incompletely recovered in the faeces, the recovery increasing with increasing maturity of the grass.

\section{Intake of possible benzoic acid precursors and urinary output of aromatic acids}

The quantities of shikimic, quinic and chlorogenic acids and 'total $o$-dihydroxyphenolic compounds' in the grasses offered to the sheep are recorded in Table 4 . The maximum urinary benzoic acid derivable from these precursors present in $\mathrm{I} \mathrm{kg}$ of

Table 7. Benzoic acid calculated to be derivable from shikimic, quinic and chlorogenic acids; total o-dihydroxyphenolic compounds in the six cuts of $S_{24}$ ryegrass given to sheep, and observed urinary output of total aromatic acids and benzoic acid in the urine of sheep given these herbages ( $g$ benzoic acid equivalent/kg food intake)

\begin{tabular}{|c|c|c|c|c|c|c|}
\hline & & Dietar & intake & & & \\
\hline & & Caffe & ic acid & & & \\
\hline & & & $\begin{array}{l}\text { From } \\
\text { excess' }\end{array}$ & & Urin & output \\
\hline Cut & $\begin{array}{l}\text { Alicyclic } \\
\text { acids* }\end{array}$ & $\begin{array}{c}\text { From } \\
\text { chlorogenic } \\
\text { acid } t\end{array}$ & $\begin{array}{l}\text { dihydroxy- } \\
\text { phenolic } \\
\text { compounds } f\end{array}$ & Total & $\begin{array}{l}\text { Benroic } \\
\text { acid }\end{array}$ & $\begin{array}{c}\text { Total } \\
\text { aromatic } \\
\text { acids§ }\end{array}$ \\
\hline I & $7 \cdot 67$ & 3.59 & $2 \cdot 71$ & r 3.97 & $6 \cdot 94$ & 10.28 \\
\hline 2 & $5 \cdot 53$ & $I \cdot 86$ & $I \cdot 63$ & 9.02 & $6 \cdot 16$ & $7 \cdot 49$ \\
\hline 3 & $3 \cdot 43$ & I. 34 & $2 \cdot 03$ & $6 \cdot 80$ & $6 \cdot 76$ & $7 \cdot 32$ \\
\hline 4 & $I \cdot 24$ & $0.4 \mathrm{r}$ & I. 49 & $3 \cdot 14$ & $5 \cdot 68$ & $6 \cdot 21$ \\
\hline 5 & 0.34 & 0.02 & $I \cdot 63$ & I.99 & $5 \cdot 35$ & 5.62 \\
\hline 6 & $8 \cdot 29$ & $2 \cdot 31$ & $2 \cdot 92$ & 13.52 & 14.37 & $16 \cdot 25$ \\
\hline
\end{tabular}

* Benzoic acid derivable from free shikimic acid, free quinic acid and the quinic acid moeity of chlorogenic acid.

+ Benzoic acid derivable from the caffeic acid moeity of chlorogenic acid.

$\mp$ Benzoic acid derivable from total o-dihydroxyphenolic compounds other than chlorogenic acid (see p. 954).

$\S$ Sum of benzoic, phenylacetic and 3-phenylpropionic acids.

grass has been calculated and is presented in Table 7 together with the observed urinary output of aromatic acids $/ \mathrm{kg}$ food by sheep given these grasses. For purposes of calculation, the $o$-dihydroxyphenolic compounds present in excess of the separately determined chlorogenic acid have been assumed to be caffeic acid. In Table 7 the theoretical amounts of benzoic acid obtainable from these precursors have been partitioned into three sources: that derivable from free quinic and shikimic acids and the quinic acid moiety of chlorogenic acid; that derivable from the caffeic acid moiety 
of chlorogenic acid; that derivable from the 'total $o$-dihydroxyphenolic compounds' in excess of chlorogenic acid. In column 5 of this table, the sum of the BAE derivable from all three possible sources is given.

There is no evidence that any of these precursors may be metabolized to phenylacetic acid so the most likely relationship would be expected to be between total intake of possible precursors and urinary benzoic acid (rather than total aromatic acid) output. However, in only two periods ( 3 and 6 , see Table 7 ) was a close relationship between intake of precursors and urinary output of benzoic acid observed. In periods $\mathrm{I}$ and 2 considerably smaller quantities of benzoic acid were excreted than were maximally derivable from the precursors studied $(7.03 \mathrm{~g}$ and $2.86 \mathrm{~g} \mathrm{BAE} / 24 \mathrm{~h}$ respectively). In contrast, during periods 4 and 5 greater quantities of benzoic acid were excreted in the urine than could have been derived from the precursors studied $(2.54$ and $3.36 \mathrm{~g} \mathrm{BAE} / 24 \mathrm{~h}$ respectively). Taken together these results would indicate that the similarities between intake of precursors and excretion of benzoic acid in periods 3 and 6 are more likely to be fortuitous than a real relationship.

\section{DISCUSSTON}

The close relationship found in these experiments between the quantities of food consumed and the urinary output of the acid fractions investigated suggest that the major portions of these acids were derived from the diets. With regard to the aromatic acids this conclusion is supported by the fact that the urinary excretion of these acids decreases to very low levels $(0.1$ to $0.2 \mathrm{~g}$ benzoic acid/24 $\mathrm{h}$ and 0.4 to $0.6 \mathrm{~g}$ phenylacetic acid $/ 24 \mathrm{~h}$ ) when sheep are starved for $4 \mathrm{~d}$ (Martin, I $969 \mathrm{~b}$ ). Two possible reasons may be put forward for the failure to observe a closer relationship between the intake of possible benzoic acid precursors and the urinary output of benzoic acid. First, the precursors considered may be only partly metabolized to benzoic acid, some being excreted unchanged or as other metabolites, and secondly, other unidentified benzoic acid precursors may be present in the diets given.

Not all animal species aromatize parenteral doses of quinic (Adamson, Bridges, Evans \& Williams, 1969) or shikimic acids and in those that do the intermediates involved have not been identified. When these acids are aromatized the intestinal microflora, rather than the animal tissues, appear to be responsible for these reactions (Asatoor, 1965; Booth \& Williams, $1963 b$; Beer et al. 1951). Quinic acid has been detected in human urine (Halpern, I960) and, after oral dosing, in the urine of various other species (Adamson et al. 1969). Benzoic acid is the main metabolic product in the urine of those species that aromatize these acids, some $70 \%$ of an oral dose of quinic acid being excreted in this form by man (Quick, 193I ; Beer et al. 195 I; Bernhard, Vuilleumier \& Brubacher, 1955; Cotran, Kendrick \& Kass, I960; Adamson, Bridges \& Williams, 1966). Sheep have been reported to excrete between 50 and $60 \%$ of an oral dose of quinic acid as benzoic acid (Vasiliu, Timosencu, Zaimov \& Cotelu, 1940). Other possible products of the microbial metabolism of quinic acid include catechol (Booth \& Williams, $1963 b$ ) and 3,4-dihydroxybenzoic acid (Scheline, 1966). The possibility also exists that quinic acid and shikimic acids may be utilized by intestinal 
bacteria in the synthesis of aromatic compounds by the shikimic acid pathway (Davis, 1958).

There is no information on the metabolism by ruminants of the caffeic acid moiety of chlorogenic acid. Compounds produced as a result of microbial metabolism in the intestines of other species include 3,4-dihydroxyphenylpropionic acid (Scheline, 1968), $m$-coumaric acid (Booth \& Williams, 1963a) and 4-vinyl catechol (Scheline, 1968). The animal tissues may then metabolize the aliphatic side-chain to give benzoic acid derivatives and the 3-hydroxyl group may be methylated (Booth et al. 1957). It is not known whether the animal or its intestinal microflora is able to completely dehydroxylate caffeic acid to yield aromatic acids.

The contribution of apparently digested lignin to the urinary output of aromatic and phenolic acids by ruminants is not known. However, grass lignins are apparently unique in possessing $p$-coumaric and ferulic acids (4-hydroxy and 3-methoxy, 4hydroxycinnamic acids respectively) attached to the surface of the polymer by very labile ester linkages (Higuchi, Ito, Shimada \& Kawamura, 1967). These linkages may be broken on digestion of lignin. In this connexion Dirscherl \& Wirtzfeld (1964) have observed small urinary increments in vanillic acid (3-methoxy, 4-hydroxybenzoic acid) on oral administration of lignin preparations to man.

Dietary phenolic acids derived from chlorogenic acid and related compounds and possibly lignin may be excreted in the urine, at least in part, as phenolic acids. The best estimate of urinary phenolic acid output in these experiments is the difference between the BAE in diethyl ether and light petroleum extracts of hydrolysed urine. In addition to phenolic acids, this fraction contains aliphatic and indolyl acids. The BAE content of this fraction varied with diet in a manner similar to the total 'caffeic acid' content of the diet (i.e. the sum of columns 3 and 4 in Table 7). Thus, for cuts $\mathrm{I}, 2,3,4,5$ and 6 the dietary intake of total 'caffeic acids' was $6 \cdot 3,3.5,3.4, \mathrm{I} \cdot 9, \mathrm{I} \cdot 7$ and $5.2 \mathrm{~g} / \mathrm{kg}$ food respectively and the urinary output of $\mathrm{BAE} / \mathrm{kg}$ food in the phenolic acid-containing fraction was $7 \cdot 3,5 \cdot 3,4 \cdot 0,3 \cdot 7,2 \cdot 8$ and $5 \cdot 6 \mathrm{~g}$ respectively. This similarity in trend may indicate the excretion of considerable quantities of phenolic acids. The apparent digestion of lignin by sheep given cuts $\mathrm{I}, 2$ and 3 was $6.7,7 \cdot 5$ and $6 . \mathrm{I} g$ lignin $/ \mathrm{kg}$ food respectively. Part of this apparent digestion of lignin may be due to removal of $p$-coumaric or ferulic acids from the lignin polymer (Higuchi et al. 1967) but part also to the removal of methoxyl groups (Bondi \& Meyer, I943). It is not possible to estimate the contribution apparently digestible lignin may make to urinary aromatic and phenolic acids in these experiments.

There is no known pathway whereby quinic, shikimic, chlorogenic or cinnamic acid derivatives could be metabolized to phenylacetic acid. However, Scott et al. (1964) have shown that a considerable proportion of the amino acid phenylalanine may be metabolized to phenylacetic acid by rumen bacteria. The results obtained by these workers did not indicate a very large excretion of phenylacetic acid in the urine (about $0.2 \%$ of the dietary phenylalanine was excreted as phenylacetic acid). In the present experiments it was observed that the excretion of phenylacetic acid in the urine varied with diet in a manner that was similar to the intake of apparently digestible nitrogen (see Tables 5 and 6). This relationship is illustrated in Fig. 2, and 
it was found that an exponential equation of the $\log _{10}$ of the urinary phenylacetic acid output ( $E, g$ phenylacetic acid/kg food intake per $24 \mathrm{~h}$ ) on the intake of apparently digestible nitrogen $(\mathrm{N}, \mathrm{g}$ apparently digestible nitrogen $/ \mathrm{kg}$ food intake per $24 \mathrm{~h}$ ) could

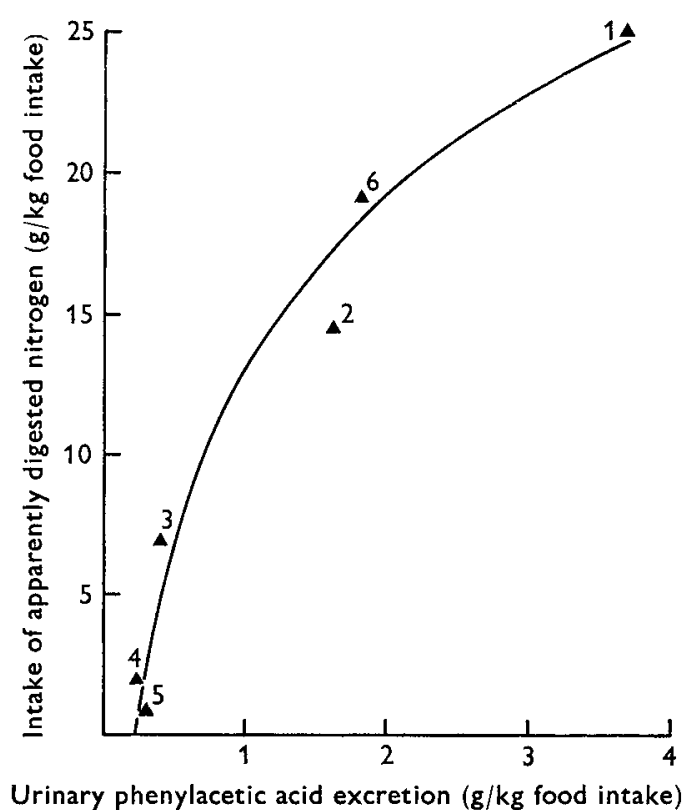

Fig. 2. Relationship between the mean intake of apparently digestible nitrogen $(\mathrm{g} / \mathrm{kg}$ food intake) and mean urinary excretion of phenylacetic acid ( $\mathrm{g} / \mathrm{kg}$ food intake) by sheep given each of the six cuts of perennial ryegrass. The line represents the equation, $\mathrm{E}=0.05 \mathrm{~N}-0.63$, where $\mathrm{E}=\log _{10}$ phenylacetic acid ( $\mathrm{g}$ phenylacetic acid $/ \mathrm{kg}$ food intake) and $\mathrm{N}=$ intake of apparently digested nitrogen $(\mathrm{g} / \mathrm{kg}$ food intake). The numbers beside each point represent the period to which that point refers.

be fitted to these values and accounted for $97 \%$ of the total variance. The equation was significant $(P<0.00 \mathrm{r})$. The equation, also illustrated in Fig. 2, was:

$$
\mathrm{E}=0.05 \mathrm{~N}-0.63 \text {. }
$$

The exponential shape of the curve may be due to the ability of some rumen microorganisms to utilize phenylacetic acid for phenylalanine synthesis (Allison, 1965). In conditions where the supply of digestible $\mathrm{N}$ was small, bacterial growth may also have been slow, and consequently the re-utilization of phenylacetic acid poor (the ratio of phenylacetic acid output ( $\mathrm{g} / \mathrm{kg}$ food intake per $24 \mathrm{~h}$ ) to apparently digestible nitrogen ( $\mathrm{g} / \mathrm{kg}$ food intake per $24 \mathrm{~h}$ ) intake was 0.35 for period 5 ) compared to conditions when more nitrogen was available and the re-utilization of phenylacetic acid may have been more efficient (the same ratio was 0.05 for period 3 ). Very large intakes of nitrogen may have led to the production of more phenylacetic acid than the microorganisms could use and thus, during periods when the nitrogen intake was large the ratio of phenylacetic acid output to digestible nitrogen intake again rose $\left(0 . I_{3}\right.$ for period 6). The relationship between phenylacetic acid (Table 5 ) and digestible protein 
intake (Table 6) needs further study, for the results plotted in Fig. 2 could also indicate that urinary phenylacetic acid was derived from some other precursor whose concentration in herbage varied in the same manner as its content of apparently digestible nitrogen. Vasiliu, Huber, Timosencu, Zaimov \& Cotelu (1940) have, however, observed increments in the urinary excretion of conjugates of benzoic acid of 0.4 to $\mathrm{I} \cdot 0 \mathrm{~g} / 24 \mathrm{~h}$ and of conjugates of phenylacetic acid of 3.7 to $4.2 \mathrm{~g} / 24 \mathrm{~h}$ on supplementation of the diet of sheep with $150 \mathrm{~g}$ of casein. Their casein preparation contained $3.9 \%$ of phenylalanine, and an intake of $5.8 \mathrm{~g}$ of phenylalanine was associated with an increased urinary output of up to $4.2 \mathrm{~g}$ phenylacetic acid.

Flavonoids may also be precursors of urinary aromatic acids. Oral administration of flavonoids to rabbits (Booth, Jones \& DeEds, $195^{8}$ ) has resulted in the urinary excretion of phenolic derivatives of benzoic and phenylacetic acids with hydroxylation patterns related to those of the $\mathrm{B}$ ring of the flavonoid. The length of the aliphatic side-chain of the resultant phenolic acid depended on the presence or absence of a 3 -hydroxyl group in the flavonoid; when present, phenylacetic acid derivatives were produced, when absent, benzoic acid derivatives were found. In the more mature herbages (cuts 4 and 5) given to sheep in these experiments, qualitative examination (A. K. Martin, to be published) revealed the presence of greater proportions of flavonoid-reacting material than in the less mature herbage.

These experiments have indicated that shikimic, quinic and chlorogenic acids are present in the herbages studied in sufficient quantity to account for a significant part of the urinary output of aromatic acids, particularly when young herbage is given to sheep. However, other precursors are also present, and further work is needed on their identification and quantitative significance in forage plants, the degree of their metabolism to aromatic acids, the intermediates involved and their possible effect on ruminant metabolism.

The author is indebted to his colleagues for helpful discussions and in particular to Dr J. H. Moore for his advice and encouragement. Dr M. E. Castle made available the pure stand of $\mathrm{S}_{24}$ ryegrass used in these experiments and $\mathrm{Dr} \mathrm{D}$. Reid advised on their management. The experimental animals were in the care of $\mathrm{Mr} \mathrm{J}$. McDill and Mr C. Park, and analytical assistance was given by Miss G. Breckenridge, Miss J. T. Begg and Miss G. Falconer.

\section{REFERENCES}

Adamson, R. H., Bridges, J. W., Evans, M. E. \& Williams, R. T. (1969). Biochem. $\mathcal{~ . ~ I 1 2 , ~ I 7 ~} P$. Adamson, R. H., Bridges, J. W. \& Williams, R. T. (1966). Biochem. $\mathcal{F}$. 1oo, 7 I $P$.

Allison, M. J. (1965). Biochem. biophys. Res. Commun. 18, 30.

Asatoor, A. M. (1965). Biochim. biophys. Acta 100, 290.

Beer, C. T., Dickens, F. \& Pearson, J. (195I). Biochem. F. 48, 222.

Bernhard, K., Vuilleumier, J. P. \& Brubacher, G. (1955). Helv. chim. Acta $3^{8}, 143^{8}$.

Bondi, A. H. \& Meyer, H. (1943), F. agric. Sci., Camb. 33, I23.

Booth, A. N., Emerson, O. H., Jones, F. T. \& DeEds, F. (1957) F. biol. Chem. 229, 5 I.

Booth, A. N., Jones, F. T. \& DeEds, F. (I958). F. biol. Chem. 230, 66r.

Booth, A. N. \& Williams, R. T. (1963a). Nature, Lond. 198, 684.

Booth, A. N. \& Williams, R. T. $\left(1_{96} 6\right.$ ) . Biochem. F. 88, 66 P.

Bray, H. G., Ryman, B. \& Thorpe, W. V. (1947). Biochem. F. 41, 2 I2.

Brigl, P. \& Pfähler, A. (1929). Tierernährung r, 3 . 
Cotran, R., Kendrick, M. I. \& Kass, E. H. (1960). Proc. Soc. exp. Biol. Med. 104, 424.

Czerkawski, J. W. (1967). Br. F. Nutr. 21, 325 .

Davis, B. D. (1958). Archs Biochem. Biophys. 78, 497.

Dirscherl, W. \& Wirtzfeld, A. (1964). Hoppe-Seyler's Z. physiol. Chem. 336, 8 I.

Ely, R. E., Kane, E. A., Jacobson, W. C. \& Moore, L. A. (1953). F. Dairy Sci. 36, 346.

Halpern, M. J. (1960). Clinica chim. Acta 5, 264.

Harbourne, J. B. \& Simmonds, N W. (1964). In Biochemistry of Phenolic Compounds p. 77 [J. B. Harbourne, editor]. London and New York: Academic Press.

Higuchi, T., Ito, Y., Shimada, M. \& Kawamura, I. (1 967). Phytochemistry 6, I 55 I.

Hill, J. T. \& Hill, I. D. (1964). Analyt. Chem. 36, 2504.

McEvoy-Bowe, E. (1966). Analyt. Biochem. 16, 153.

Martin, A. K. (1966). Br. F. Nutr. 20,325.

Martin, A. K. (1969a). Br. F. Nutr. 23, 389 .

Martin, A. K. ( I $969 b)$. Br. F. Nutr. 23, 7I5.

Pazur, J. H. \& DeLong, W. A. (1948). Scient. Agric. 28, 39.

Quick, A. J. (193 I). F. biol. Chem. 92, 65.

Scheline, R. R. (1966). Acta pharmac. tox. 24, 275.

Scheline, R. R. (1968). Acta pharmac. tox. 26, 189.

Scott, T. W., Ward, P. F. V. \& Dawson, R. M. C. (1964). Biochem. F. 90, 12.

Taussky, H. H. (1956). Clinica chim. Acta I, 2 го.

Van Niekerk, B. D. H., Reid, J. T., Bensadoun, A. \& Paladines, L. O. (1963). F. Nutr. 79, 463.

Vasiliu, H., Huber, Z., Timosencu, A., Zaimov, C. \& Cotelu, V. (1940). Bul. Fac. Şti. agric. Chişinău 3, 29.

Vasiliu, H., Timosencu, A., Zaimov, C. \& Cotelu, V. (1940). Bul. Fac. Şti. agric. Chişinău 3, 77.

Zucker, M. \& Ahrens, J. F. (1958). Pl. Physiol., Lancaster 33, 246. 